Elena R. Menshikova

Candidate of Cultural Studies

Expert New Institute for Cultural Research e-mail.com:elen_menshikova@mail.ru

Moscow, Russia

OCRID 0000-0002-5738-0732

DOI: $10.36340 / 2071-6818-2019-15-4-24-42$

\title{
The natural landscape of philosophy (the political reflection of Heraclitus and Aristotle)
}

Summary: Civilizational breakthrough of "axial time", implemented «human band» in the middle of the first millennium BC practically simultaneously in different latitudes of our planet - this is the time of the birth of science and arts, the development of language as a literary tradition, the becoming of Myth as an active picture of the world - a subjective objective, a philosophical understanding of what is the person and being that surrounds him and what he creates, and formation of knowing the world by the word and deed of the subject and, at the same time, the thinking object possessing political reflection. However, political reflection has one significant drawback - the brevity of historical memory, which should from time to time be brought to life, refreshing the milestones of events and the wisdom of others' reflections, so that cognitive dissonances do not arise freely (arbitrarily) or malicious aforethought of political phenomena (war, state, strategist-politician, political power, etc.), breaking the membrane of human hostel - ethos, the philosophy of culture, art with science and the craving for work. The twentieth century (and lasting the first quarter of the $21^{\text {st }}$ century), as a vivid illustration of endless wars and permanent revolutions, as an age of world and local conflicts, demonstrating an indissoluble connection with the ancient myth, the $20^{\text {th }}$ scattered the teeth of mythology, rehashing the world and the principles of the state, destroying boundaries and the empire, unleashing new wars, multiplying ethnic conflicts, sweeping away valued reference point and changing anthropological signs, disagreeing with the essential in man: depriving the Word and the Cause.

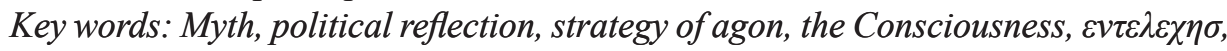
prosperity, mythologies, epistemology, responsibility ( $\varepsilon v \delta \varepsilon \mu o v l \alpha)$, cultural code.

The Greek vocabulary has a rich enough semantics to conduct an etymological and linguistic analysis of one or another reasoning of the ancient philosopher for those dribs and drabs that the reconstruction (sometimes virtuosic) of fragments of Heraclitus and Stagirite gives us, to make for ourselves not just a general idea, but to see the picture of ideas (in the totality of the plan) and the way of thinking of both the first and the second, without the pressure of other people's interpretations, is quite feasible task for everyone who having joined on the path of self-knowledge, has embarked on self-realization. ${ }^{1} \mathrm{At}$ 


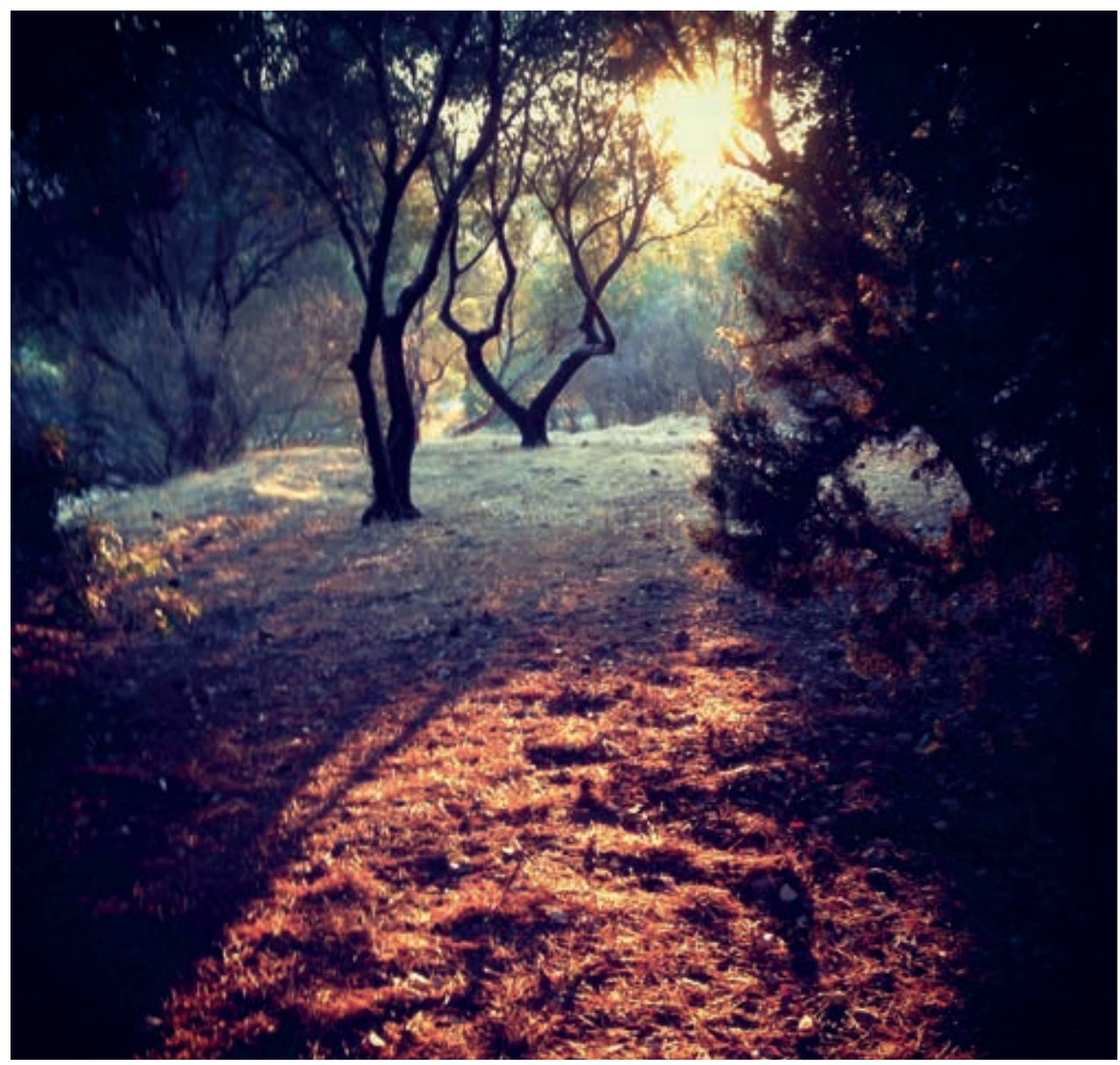

Pniks, a neighborhood near the Acropolis, the place where Socrates was judged. Photo was taken in 2013, during the World Congress of Philosophy in Athens.

the same time, not tired to ask yourself the same questions: who am I? why am I? why me? Both thinkers turned their views to their contemporaries, and therefore they aspired not only to be understood, not conditionally accepted by the crowd of adepts, but to be in tune with the mood and flow of time, grasp the nerve of being, as a bursting bowstring, and pull it with strings of lyre - Heraclitus could express so it and could teach others to cope with the fetters of consciousness that liken a person to a retiarius catching his own shadow, as Aristotle did it when nurturing Alexander, therefore the language and the structure of their language were not complex, but were rich in images and were accurate characteristics. It was their "political reflection" - to direct their thoughts outside-in being-in-the-world-to send their thinking to the Absolute of the possible: directing and nurturing the consciousness of the Other and the Alien, so that someday it would become His. At the same time, both philosophers never lived in an ivory castle - on the contrary, - always in the midst of the people (one was a successful trader) 
and at the peak of social changes (the court and pedagogical activities of the second). We can say that the natural landscape of philosophy is defined by two of its tireless surveyors, Heraclitus and Stagirite, the political reflection of the person (their - in the first place) is formulated properly clear - by their efforts - to be, one must do his work as best as possible (with knowledge, perfection of one's own knowledge, aspirations to comprehend the truth), realizing that it is necessary to make the maximum of skills and knowledge, that gives an understanding of one's own happiness, which is in harmony with the world and the harmony with oneself - gnosis (understanding) comes in the light of epistemes (knowledge) and remains with the person creating the music of the spheres for him. Political reflection by Heraclitus and Aristotle is aimed at society: for improvement, perfection, existence in it, when a person, changing, changes it, alternating the tension of energies, like the tension of the lyre and bow, mentioned by the crying pre-Socratic Heraclitus, because the universe, space and our life, with its rhythms and winds, objects and organisms - everything that is based on harmony, reaches out to it and requires harmonization - are based on this change. Such an understanding was given by the landscape that nurtured the minds of both Heraclitus and Aristotle - the Achaean melik, Homer and Myth - it was exactly that "mother's milk", which became "arrows of knowledge" for millions. However, the misfortune of many people that alien credo does not always become "the personal state of Idaho", since for harmony it is important that the thought-expression, passing through the will, be refracted into the episteme of oneself and life, clothed in a concrete accomplishment, if you want, a feat $-\alpha \theta \lambda o \zeta-\mathrm{a}$ step towards the world and itself, it is this ascent and insight that gives happiness, the only thing to which a man should strive with all his soul and thoughts, according to Aristotle.

And such a "natural landscape" is the Myth - it was its space, its terra nova, that weaved the atmosphere, which allowed the emergence of the nutrient environment from which the natural philosophers came - the first as cosmonauts who gave not only the first knowledge of the cosmos and chaos, but also the rules of walking - that straight walk in the weightlessness of being, its inevitable constancy of chaos, which will become the cosmos for the first man, as the only possible home, habitat and the limit of existence, and remains so to this day - already for a reasonable and technocratic person. Myth allowed not only to breathe, but was that "natural exchange", which formed the basis for the "Socratic dialogue" of the first thinkers, providing themselves as a lullaby or cradle to all philosophical schools and religious currents. And as the atmosphere of perception and imagination that is generous to ozone, Myth continues to feed our consciousness and develops the political reflection of everyone who is immersed in it. The snag is in one - in the degree of development of this consciousness, in readiness to develop this consciousness: constantly, diligently, the wheels of which we are accustomed to twist to the scattered everywhere maxims of natural philosophers.

The model of the dual perception and reflection that reigned in the mind of an ancient person, this double aspect of the worldview, found its reflection not only in the musike forms of art (from «Gigalmesh» and «Rāmāyana» to «The Iliad» and «The Works and 
Days», satirical dithyrambs and Greek`s lyric poetry, vase painting, Aristophanes's comedies, Euripides 's dramas), but in the pre-Socratian utterances about world harmony, which is possible only when "tension alternates with weakening like a lyre and an bow" [Vors. I, 12, B51], because "the universe is in harmony with itself, while parts of it often feud." [Plotinus, III, 2 [47], 16, 48 H.-S.] ${ }^{2}$. Heraclitus considered the opposites as gods (Philodemus, On piety, 6a, 70; Gomperz) ${ }^{3}$ and believed that the alternation of opposites is inevitable [Plotinus, IV, 8 [6], 1, 11 H.-S.], as night and day, and therefore fate called mind [logos]. As the "creator of all things through «running in opposite sides»»»", and that is why "all things move, changing places among themselves, and do not stand still" [Hippolytus Disclaimer, I, 4, 2; Dox. 559] ${ }^{5}$ - this thesis of Heraclitus will form the basis of his natural philosophy, which will be caught by minds of many (this principle of exchange-the run of opposites Lucian calls "the sale of lives"), reproducing literally in life: "[Etalid] at the same time mourned and mocked the impermanence of life" [John Tzetzes. Iliad, II, 723, Leone $]^{6}$. O. Freidenberg called this the hybrid of the ancient Greeks, we call the dichotomy of the tragic and the comic, based on the same inevitable run of opposites, alternating night-day, light-shadow, tears-laughter. This idea came from the depths of the people - the Myth of Dionysus and the Myth of Osiris was woven by all: collegially, which was associated with faith in the natural forces of the earth, their ordering and reasonableness, with the search for harmony that turns out to be "tense in opposite sides and shooting arrows through opposites" [Porphyry. About the cave of nymphs, 29] ${ }^{7}$. And it is taking him as an immutable, common $(\xi \vee \varphi)$ for all, the rule of life, Plutarch explains the origins of such a vision and sees the cause of the emergence again by Heraclitus: in polemos, because "having no creator of his own beginning, but possessing a firm and unshakable conviction and spreading not only through narration and tradition, but also through the mysteries and rituals of sacrifice everywhere - from Greeks and from barbarians: The Universality fluctuates outside of reason, law and government not by itself, not the single Reason rules it and directs it like a rudder or power bit, but how nature contains in itself much, and in the mixture of good and evil, or, as it is better said, does not have nothing unmixed in this world, ... from two opposite beginnings and two hostile forces, one of which leads us to the right and the right road, and the other turns back and leads to a side, a complex life and peace, if not all, this earthly and sublunary, heterogeneous, motley and subject to any changes. And if nothing comes without a cause, and the good could not contain the cause of evil, then nature must have a special start and a special source for good, so for evil". Heraclitus himself defines the reason: "The war (Polemos) is the father of all, the king of all: it declares one gods, others - men, ones - slaves, others - free" [Hippolytus, IX, 9.4 (c.242, 5W)], and therefore everyone should know that "... war is generally accepted that the feud - the usual order of things $(\delta \iota \chi \eta)$, and that everything arises through hatred and on loan [at the expense of another]" [Kelsen in Origen, Against Kelsen, VI, 42, II, c. 111, 9 Koetschau ]'. In a word, dual perception follows from the general picture of the world, the essence of which is war. The history of mankind stretches on the spearhead, jumps from the world to war, spears a changeable world prone to 
squabbles and provocations, using the dual, contradictory nature of man, which for millennia is difficult to transform (the psychophysics of man is unchanged), and does not know how to restrain one's own Emotions, instead of art of compromise, studying the science of conflictology, builds its political reflection only on the basis of hostility, and, now, benefits. But were not all the armed conflicts, the revolutions of Rome, the persecutions of Christians, and then the execution of the heathens, the invasion of the Huns, the crusades, witch-hunts, colonial wars, peasant wars, color revolutions with a double bottom? Is it not "borrowed, at the expense of another"? Many centuries later, Darwin will put this principle in the basis of his theory of evolution - natural selection as a result of war and enmity species.

Note that this was written after St. apostle Paul by his younger contemporary Plutarch, on which the heat Epistles visionary did not work magically, and who had remained faithful to the wisdom sayings of Heraclitus: "Who is going to speak [="mouthing their logo"] with the mind ( $\xi v v v o \varphi)$, they should be based м $(\xi v v \varphi)$ for all citizens as a policy - by law, and even much stronger. For all human laws depend on one, the divine: it extends its power as far as it wills, and everything bears down, and everything transcends [Stobaeus III, 1, 179; III, c. 129 H. ("On Virtue")] ${ }^{10}$. And as if, seeing the future, Plutarch will gain another support of Heraclitus: "For the awake there is

one common world, and from the sleeping one turns to his own. For the superstitious, no world is common, for it is devoid of common sense in reality, and in a dream it can not get rid of fears "[Plutarch. On superstition $166 \mathrm{C}]^{11}$.

\section{REFERENCES}

1. Plutarch. 2006. Isis and Osiris, p. 463.

2. Plotinus, III, 2 [47], 16, 48 H.-S. - Eraclito. Fragmente [Die Fragmente der Vorsokratiker. Grichisch und Dentsch von HERMANN DIELS, hrsg. V. W. KRANZ, Bd. I-III. B., 1951-1952] by Russian translation: Heraclitus of Ephesus. Fragments of the early Greek philosophers. C. I. - M.: Publishing House «The Science», 1989. P. 576.

3. Philodemus. On piety, 6a (p. 70 Gomperz). - Eraclito. Fragmente [Die Fragmente der Vorsokratiker. Grichisch und Dentsch von HERMANN DIELS, hrsg. V. W. KRANZ, Bd. IIII. B., 1951-1952 ] by Russian translation: Fragments of the early Greek philosophers. C. I. M.: Publishing House «The Science», 1989. P. 576.

4. Plotinus, IV, 8 [6], 1, 11 H.-S. - Heraclitus. Fragments. Fragments of early Greek philosophers. Part I. - M.: Publishing House "Science", 1989.

5. Hippolytus. Refutation, I, 4, 2 (Dox. 559). - Heraclitus. Fragments. Fragments of early Greek philosophers. Part I. - M.: Publishing House "Science", 1989.

6. John Tzets. Iliad, II, 723, Leone. - Heraclitus. Fragments. Fragments of early Greek philosophers. Part I. - M.: Publishing House "Science", 1989.

7. Porphyry. About the cave of nymphs, 29. - Heraclitus. Fragments. Fragments of early Greek philosophers. Part I. - M .: Publishing House "Science", 1989.

8. Plutarch. Isis and Osiris. - M.: Exmo, 2006. P. 463.

9. Hippolytus, IX, 9.4 (p. 242, 5W), Kels at Origen, Against Kels, VI, 42, (II, p. 1111, 9 Koetschau). - Heraclitus. Fragments. Fragments of early Greek philosophers. Part I. - M .: Publishing House "Science", 1989.

10. Stobaeus, III, 1, 179 (III, p. 129 H.) (“About Virtue”). - Heraclitus. Fragments. Fragments of early Greek philosophers. Part I. - M .: Publishing House "Science", 1989. 
11. Plutarch. About Superstition, 166. - Heraclitus. Fragments. Fragments of early Greek philosophers. Part I. - M .: Publishing House "Science", 1989.

12. Mythology: Illustrated Encyclopedic Dictionary. - SPb., 1996. P. 790.

13. Menshikova, E. 2009. The Grotesque consciousness: the phenomenon of the Soviet Culture, p. 296.

14. Stobaeus, III, I, 176. - Heraclitus. Fragments. Fragments of early Greek philosophers. Part I. - M .: Publishing House "Science", 1989.

15. Losev A. F. 1990. Dialectics of the Myth. Losev A. F. From early works. - M.: Publishing house "Pravda," P. 656.

16. Chrysipus of Plutarch, About the contradictions of the Stoics, 1049F (= SVF II, No. 937). - Heraclitus. Fragments. Fragments of early Greek philosophers. Part I. - M .: Publishing House "Science", 1989.

17. Lucian. Sale of lives, 14. - Heraclitus. Fragments. Fragments of early Greek philosophers. Part I. - M .: Publishing House "Science", 1989.

18. Menshikova, E. 2000. “The Carnival consciousness”, Discourse, 2000. № 8/9, pp. 19-26.

19. Diogenes Laërtius, IX, 7. - Heraclitus. Fragments. Fragments of early Greek philosophers. Part I. - M .: Publishing House "Science", 1989.

20. Dawson K. G. Revolution gods. - St. Petersburg: Aletheia, 2002. p. 332.

21. Baudrillard J. Labor and death. Jean Baudrillard. Symbolic exchange and death. - M.: Dobrosvet, 2000.

22. The Etymological dictionary of the Russian language in the $4 \mathrm{tt}$. Vol. 3, Fasmer M. $4^{\text {th }}$ ed. M.: Astrel. AST, 2007. P. 832.

23. Menshikova, E.R. 2017. "The Myth as natural exchange (epistemological aspects of practical lie)”, Credonew, №v1, 2, 3.

24. Menshikova, E.R. 2017. "The Natural Landscape of Philosophy (political reflaction of Heraclitus and Aristotle)", 29 th International Conference of Philosophy "Greek moral and political philosophy-From Pre-Socratics to Neo-Platonism” (Jule 7-11, 2017, Rhodes). Paper Abstracts, Rhodes,.

25. Menshikova E. R. 2018. "The Natural Landscape of Philosophy (The Political Reflection of Heraclitus and Aristotle)", Philosophy Study, vol. 8, no.1

\section{ENDNOTES}

26. Original article is written in Russian, has been adapted to English for presentation at the $29^{\text {th }}$ INTERNATIONAL CONFERENCE OF PHILOSOPHY "GREEK MORAL AND POLITICAL PHILOSOPHY (FROM PRE-SOCRATICS TO NEO-PLATONISM) (RHODES: $7^{\text {th }}-12^{\text {th }}$ JULY 2017), where it was read in the quality of the report on 07/10/2018.

27. Heraclitus of Ephesus. The first sentence quoted by: Plutarch. Isis and Osiris. Decree. Op. P.54, second on: Fragments of the early Greek philosophers. C.I. - M.: Publishing House «The science», 1989. C.200.

28. Fragments. P.237

29. Opinions of philosophers I, 7, 22. Qu. By: Fragments. P.204. Cf. Also: "The life of man usually resembles a ladder, for it is full of ups and downs" (Philo Alex., On Dreams, I, 153 (III, c.237 W.)

30. Fragments. P.213

31. Ibid. P. 213

32. Ibid. P.200

33. Plutarch. Decree. Op. S.54-55. We specially quote such an extended quotation to show that Plutarch's view of the culture of the past with more than a thousand-year history based on myths that are reflected in all the Musical arts is extremely objective, because it is integral to the views of Heraclitus, one of the founders of Greek natural philosophy.

34. Fragments. P.201.

35. Fragments. P.197. And not without irony, apparently already in the transfer of Sextus Empiricus, Heraclitus says: “... although the mind - Society, most people live as if they had

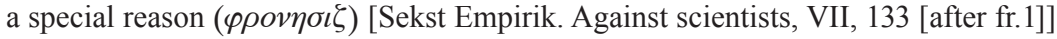

36. Fragments. P.198. 
Елена Рудольфовна Меньшикова кандидат культурологии эксперт

Новый Институт Культурологии e-mail:elen_menshikova@mail.ru

Москва, Россия

OCRID 0000-0002-5738-0732

DOI: $10.36340 / 2071-6818-2019-15-4-24-42$

\section{Натуральный ландшафт философии ( политическая рефлексия Гераклита и Аристотеля) $^{1}$}

Аннотация: Цивилизационный прорыв «осевого времени», осуществленный human band в середине первого тысячелетия до н.э. практически одновременно в различных широтах нашей планеты, - это время рождения наук и искусств, развития языка как литературной традиции, становления Мифа как действующей картины мира - субъективного объектива, философского понимания, что есть человек и бытие, окружающее его и творимое им, и формирования познающего мир словом и делом субъекта и, в тоже время, мыслящего объекта, обладающего политической рефлексией. И таким «натуральным ландшафтом» оказывается Миф - именно его пространство, его terra nova, соткало ту атмосферу, что позволила возникнуть той питательной среде, из которой вышли натурфилософы - первые, словно космонавты, давшие не только первые знания о космосе и хаосе, но и правила хождения - того прямохождения в невесомости бытия, его неотвратимом постоянстве хаоса, что станет космосом для первого человека, как единственно возможным домом, средой обитания и пределом существования, и остается таковым и по сей день - уже для человека разумного и технократичного. Миф позволил не только дышать собой, но явился тем «натуральным обменом», что лег в основу «сократического диалога» первых мыслителей, предоставив себя в качестве колыбельной иль люльки всем философским школам и религиозным течениям.

Ключевые слова: политическая рефлексия, этос, агон, труд, Сознание,

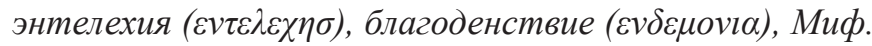

Античные корни, пронизывающие не только европейскую и русскую культуры (вне зависимости от континента обитания), но и, как показал год Аристотеля (2016), отмечаемый во всем мире как «пир эйдоса и духа на весь мир», эпистемологиче-

1. Статья была специально написана для 29th INTERNATIONAL CONFERENCE OF PHILOSOPHY "GREEK MORAL AND POLITICAL PHILOSOPHY (FROM PRE-SOCRATICS TO NEOPLATONISM) (RHODES:7th-12th JULY 2017) на русском языке, переведена и прочитана в качестве доклада (на англ. языке) 10.07.2017 г. на площадке конференции в г. Родос. 
ски скрещены и с восточной традицией (Междуречья, Индии, Китая), храня в себе результаты «осевого времени» - цивилизационного прорыва, осуществленного human band в середине первого тысячелетия до н.э. практически одновременно в различных широтах нашей планеты. Это время рождения наук и искусств, развития языка как литературной традиции, становления Мифа как действующей картины мира - субъективного объектива, философского понимания, что есть человек и бытие, окружающее его и творимое им, и формирования познающего мир словом и делом субъекта и, в тоже время, мыслящего объекта, обладающего политической рефлексией. (Это суждение не дань популизма, но лишь вводное замечание, призванное обнаруживать связь культур через грибницу Мифа самостоятельно с тем, чтобы увлекательнее было открытие нового, чтобы мысль летела, и была свободна в выборе маршрута, собирая феномены на своем пути, словно нектар душистых прерий.)

Однако политическая рефлексия имеет один существенный недостаток краткость исторической памяти, которая должна время от времени приводиться в чувство, освежая вехи событий и мудрость чужих рефлексий, с тем, чтобы не возникали когнитивные диссонансы вольно (произвольно) или злым умыслом политических феноменов (войны, государства, стратега-политика, политической власти и пр.), ломающих мембраны человеческого общежития - этос, философию культуры, искусство вместе с наукой и тягой к труду. Последние пять лет показали, что человечество, объятое пылью войн и конфликтов, готово к новой гигантомахии - «распре без правил», и уже пишет новые страницы в словарь мифологий. XX век (и длящаяся первая четверть XXI в.), как яркая иллюстрация нескончаемых войн и перманентных революций, как век мировых и локальных конфликтов, демонстрируя неразрывную связь с античным мифом, XX-й рассыпал зубья мифологий, перекраивая мир и принципы государства, разрушая границы и империи, развязывая новые войны, множа этнические конфликты, сметая ценностные ориентиры и меняя антропологические признаки, расподобляя сущностное в человеке: лишая Слова и Дела.

$\mathrm{XX}$ век показал, что human band разрушается не только коллективизмом, но и рефлексией праздного удовольствия, что выражается в прямо пропорциональной зависимости качественных изменений от количественных, - так, следование древнему закону проскрипций, воспринимаемый большинством как экзамен на зрелость, низводя классические идеалы в ширпотреб. Разгром империй вскрыл Пандоры короб горящей лавой национализма и фундаментализма, что неминуемо потребовали для себя уложений и монархических регалий, в сказ обращая террор, этнические чистки, разбойные банды, романтизируя убийц и пиратов, шлюх и воров - представителей антимира, требующих своей институализации, коммуникативную стратегию культуры пуская вектором расподобления вниз - в антимир - путая полярные знаки, что и накрывает властью Тьмы. 
Новое Средневековье наступает со скоростью кванта емкостью бита ставит проблему угасания human band в царстве технического прогресса и при всей своей парадоксальности и трагическом абсурдизме все меньше рождая гениев, ответственность отпуская на волю случая случаем, как праздного гуляку, однако нестабильность самой реальности чем сильнее, тем громче заявляет, что для human band нет ничего существеннее и важнее $\alpha \lambda \eta \theta \varepsilon 1 \alpha-$ истины, отыскание которой поручается Сознанию, и это естественное право стратегического мышления обнаружить правду: проявляясь осмыслить - мысленно фиксируя себя и время. Это право из покон веков человеку вручал Миф, но сегодня он уподоблен призу, которого удостаивается не всякий проникший в студию реального бытия. Человека глушат страстями и симулакрами, уводя (не подпуская) от политической рефлексии, картину мира - мировоззрение - заменяя на «виды халдейски» лубочных картинок презентаций, на визуальные игры клиповой мании постмодерна. Когнитивный диссонанс создает лакуны восприятия действительности, и, как следствие, ведет к дислексии сознания, атрофии мыслительных способностей человека.

Прошлый век заявил о глобальной проблеме утраты смыслов, решение которой лишило бы возникший когнитивный диссонанс поколений гиперболической агрессии, вернув понимание (в эпистемологическом, философском, мировоззренческом смысле) в сферу человеческой жизни. Когда говорят о государстве, то нередко употребляют слово «махина» - греческого происхождения от - $\mu \alpha \chi \eta, \mu \alpha \chi \eta \zeta, \mu \alpha \chi \mu о \zeta$ - сражение, битва, воинственный, намекая таким образом (или же просто по инерции генетической памяти), что политическая философия всякого государства

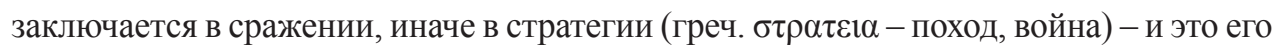
суть. Это естественное право политической рефлексии государственной машины. Но эта же махина, работающая благодаря своим винтикам, может ломаться из-за

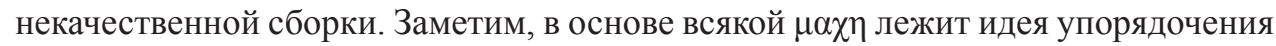
мира, а нынешняя ситуация наводнения мифологиями провоцирует беспорядок и смятение чувств. Как сохранить человека для человечества - фундаментальная проблема, оставленная академиком С. Капицей, как парадоксальное завещание другу парадоксов - гению, тем, быстрым разумом невтонам, которых взращивал академик М. Ломоносов, когда политическая стратегия государства не хромала на обе ноги. По мысли А. Пятигорского, быть современным, иначе, скажем, чувствовать актуальность времени, означает «смотреть на прошлое из отрефлексированной тобой самим современности». (Заметим, с чем успешно стравляется «гротескное сознание» художника, порой провокативно, но цепко и метко: абсолютом боли бъёт в точку понимания происходящего, высекая абсолют смысла двойным отражением - трагикомичным.) Словом, считывая противоречия бытия-в-миpe, сматывая в клубок рефлексий, бросать их нужно Клио, чтобы та тянула нити понимания, сплетая нашему сознанию волшебные рубашки разумения (аллюзия на диких лебедей Андерсена), чтобы вернуться в правое поле стратегического мышления, отстояв свою основную примету: Человек и Слово (К. Кавафис). Но 
осознанная, отрефлексированная современность, возможна лишь в сознании, а сознание формирует Миф - та питательная среда, без которой мыслительная мышца обмякнет или атрофируется вовсе, и вот политическая рефлексия, которой нас наделяет Миф, позволяет вырабатывать собственную тактику в этой битве объективаций, вечной распре, именуемой жизнью.

Греческий словарь обладает достаточно богатой семантикой, чтобы, проводя этимологический и лингвистический анализ того или иного умозаключения античного философа по тем крохам, что дарит нам реконструкция (порой виртуозная) фрагментов Гераклита и Стагирита, составить для себя не просто общее представление, но узреть картину представлений (в целокупности замысла) и образа мыслей и первого, и второго, без прессинга чужих интерпретаций, вполне посильная задача, необходимая каждому, кто, вступив на путь самопознания, приступил к самореализации, при этом, не уставая задавать себе одни и те же вопросы: кто я? зачем я? почему я? Оба мыслителя обращали свои взгляды к своим современникам, а потому стремились быть не только понятыми, не условно принимаемы толпой адептов, но быть созвучными настроению и течению времени, схватывать нерв бытия, словно лопнувшую тетиву лука, и натягивать ее струнами лиры - так бы мог выразиться сам Гераклит, и научить других справляться с путами сознания, которые уподобляют человека ретиарию, ловящего собственную тень, как это делал Аристотель, пестуя Александра, - оттого и язык, и строй языка их не был сложен, но богат на образы и точен характеристиками. Это была их «политическая рефлексия» - направлять свои мысли во вне - в бытие-в-мире - посылать свое мышление в Абсолют возможного: направляя и взращивая сознание Другого и Чужого - так, чтобы когда-нибудь оно стало Своим. При этом, оба философа никогда не жили в замке из слоновой кости - напротив, всегда в гуще народа (один был успешным торговцем) и на пике социальных перемен (придворная и педагогическая деятельность второго). Можно сказать, что натуральный ландшафт философии определяют два ее неустанных землемера - Гераклит и Стагирит, чьими стараниями политическая рефлексия человека (и их в первую очередь) сформулирована должным образом вполне ясно: чтобы быть, нужно делать свое дело, как можно лучше (со знанием, совершенствованием собственных знаний, устремлениями к постижению истины), понимая, что при этом необходимо прилагать максимум умений и знаний, что, дарит понимание собственного счастья, которое заключается в гармонии с миром и ладу с самим собой - гнозис (понимание) приходит в лучах эпистем (знания) и остается с человеком, создавая для него музыку сфер. Политическая рефлексия, по Гераклиту и Аристотелю направлена на общество: на улучшение, совершенствование, существование в нем, когда человек, меняясь, изменяет его, чередуя натяжение энергий, подобно натяжению лиры и лука, о которых говорил плачущий досократик Гераклит, поскольку на этой перемене зиждется вселенная, космос и наша жизнь, с ее ритмами и ветрами, объектами и организмами - все то, что основано на гармонии, тянется к ней и 
требует гармонизации. Такое понимание давал тот ландшафт, который взрастил умы и Гераклита, и Аристотеля, - ахейская мелика, Гомер и Миф - это было то «молоко матери», которое стало «стрелами познания» для миллионов. Однако, беда многих, что чужое кредо не всегда становится «личным штатом Айдахо», поскольку для гармонии важно, чтобы мыслеизъявление, проходя через волеизъявление, преломлялось в эпистему себя и жизни, облекаясь в конкретное свершение, если хотите, подвиг - $\alpha \theta \lambda$ $\zeta$ - шаг навстречу миру и себе, именно то восхождение и прозрение, что и дарует счастье, единственное к чему должен стремиться человек всей душой и помыслами, по мнению Аристотеля.

И таким «натуральным ландшафтом» оказывается Миф - именно его пространство, его terra nova, соткало ту атмосферу, что позволила возникнуть той питательной среде, из которой вышли натурфилософы - первые, словно космонавты, давшие не только первые знания о космосе и хаосе, но и правила хождения - того прямохождения в невесомости бытия, его неотвратимом постоянстве хаоса, что станет космосом для первого человека, как единственно возможным домом, средой обитания и пределом существования, и остается таковым и по сей день - уже для человека разумного и технократичного. Миф позволил не только дышать собой, но явился тем «натуральным обменом», что лег в основу «сократического диалога» первых мыслителей, предоставив себя в качестве колыбельной иль люльки всем философским школам и религиозным течениям. И как щедрая на озон атмосфера восприятия и воображения, Миф продолжает питать наше сознание и вырабатывает политическую рефлексию каждого, кто окунается в него. Загвоздка в одном - в степени развития этого сознания, в готовности это сознание развивать: постоянно, усердно, ведь сознание и есть тот самоорганизующийся хаос, крутить колесики которого нас приучают разбросанные всюду максимы натурфилософов.

Модель двойственного восприятия и отражения, царившего в сознании древнего человека, этот двойной аспект мировосприятия, нашедший свое отражение не только в мусических видах искусства (от «Гигальмеша» и «Рамаяны» до «Илиады» и «Трудов и Дней», сатирических дифирамбах и лирике греков, вазовой живописи, комедиях Аристофана, драмах Еврипида), но в речениях досократиков о мировой гармонии, которая возможна лишь, когда «напряжение чередуется с ослаблением как у лиры и лука» [1, с. 54], поскольку «универсум в ладу с самим собой, тогда как части его зачастую враждуют [2, с. 200]. Гераклит считал противоположности богами [3, с. 237] и полагал, что чередование противоположностей, как ночьдень, и потому судьбой нарекал разум [логос] как «творца всех вещей посредством «бега в противоположные стороны»» $[4, \text { с. 204 }]^{2}$, и именно поэтому «все вещи движутся, меняясь между собой местами, и не стоят на месте» [5, с. 213] - этот тезис Гераклита ляжет в основу его натурфилософии, что подхватят умы

2. Ср. также: «Жизнь человеческая обыкновенно напоминает лестницу, ибо она полна взлетов и падений» (Филон Алекс. О сновидениях, I, 153 (III, с. 237 W.) - Фрагменты. Указ. изд.). 
многих (этот принцип обмена-бега противоположностей Лукиан назовет «продажей жизней»), воспроизводя буквально в жизни: «[Эталид] одновременно оплакивал и осмеивал непостоянство жизни» [6, с. 213]. Ольга Фрейденберг называла это 'гибризмом' древних греков, мы называем «дихотомией трагического и комического», в основе которых один и тот же неизбежный бег противоположностей, чередуемый ночь-день, свет-тень, слезы-смех. Это представление шло из глубин народа - Миф о Дионисе и Миф об Осирисе ткался всеми: коллегиально, что сопряжено было с верой в природные силы земли, их упорядочении и разумности, с поиском гармонии, которая оказывается «натянута в противоположные стороны и стреляет из лука посредством противоположностей» [7, с. 200]. И именно принимая его как непреложное, общее ( $v v \phi)$ для всех, правило жизни, Плутарх объясняет истоки такого видения и видит причину возникновения опять же по-гераклитовски: в полемос, потому что «не имея творца своего начала, но обладая твердой и непоколебимой убедительностью и распространяясь не только через рассказ и предание, но также через мистерии и обряды жертвоприношения везде - и у греков, и у варваров: не сама по себе колеблется Всеобщность вне разума, закона и управления, не единый Разум правит ею и направляет ее как бы рулем или властными удилами, но как природа содержит в себе многое, причем в смешении добра и зла, или, как лучше сказать, не имеет в этом мире ничего несмешанного, ... из двух противоположных начал и от двух враждебных сил, из которых одна ведет нас направо и по верной дороге, а другая поворачивает вспять и уводит в сторону, произошла сложная жизнь и мир, если не весь, то этот, земной и подлунный, неоднородный, пестрый и подверженный всяким переменам. И если ничто не возникает без причины, а добро не могло бы содержать в себе причину зла, то природа должна иметь особое начало и особый источник как для добра, так для зла» [8, с. 54-55] $]^{3}$ Сам же Гераклит так определяет причину: «Война (Полемос) - отец всех, царь всех: одних она объявляет богами, других - людьми, одних творит рабами, других - свободными», и поэтому все должны знать, что «...война общепринята, что вражда - обычный порядок вещей ( $\delta \imath\rceil)$, и что все возникает через вражду и заимообразно [за счет другого]» [9, с. 201]. Словом, двойственное восприятие следует из общей картины мира, суть которой - война. История человечества тянется на острие копья, скачет от мира к войне, копьем вращает переменчивый мир, склонный к склокам и провокациям, используя двойственную, противоречивую, природу человека, который на протяжении тысячелетий сложно поддается трансформациям (психофизика человека неизменна), и не умеет сдерживать свои эмоции, вместо искусства компромисса изучая науку конфликтологию, выстраивает свою политическую рефлексию только на основе враж-

3. Расширенная цитата необходима, чтобы показать, что взгляд Плутарха, исследовавшего культуру прошлого более чем с тысячелетней историей, опиравшегося на мифы, что нашли свое отражение во всех мусических искусствах, предельно объективен, поскольку целокупен воззрениям Гераклита, одного из основоположников греческой натурфилософии. 
ды, и, теперь уже, выгоды. Но не так ли протекали все вооруженные конфликты, революции Рима, гонения на христиан, а затем казни язычников, нашествие гуннов, крестовые походы, гонения на ведьм, колониальные войны, крестьянские войны, цветные революции с двойным дном? Разве не «заимообразно, за счет другого»? Много веков спустя Дарвин положит этот принцип в основу своей теории эволюции - естественный отбор в результате войны и вражды видов.

Заметим, это было написано после Св. Апостола Павла его младшим современником - Плутархом, на которого жар Посланий визионера не подействовал магическим образом, и который оставался верен мудрости изречения Гераклита:

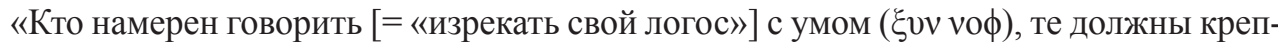
ко опираться на общее ( $\xi v v \phi)$ для всех, как граждане полиса - на закон, и даже гораздо крепче. Ибо все человеческие законы зависят от одного, божественного: он простирает свою власть так далеко, как только пожелает, и всему довлеет, и все превосходит [10, с. 197] ${ }^{4}$. И словно, прозревая будущее, Плутарх заручится еще одной поддержкой Гераклита: «Для бодрствующих существует один общий мир, а из спящих каждый отворачивается в свой собственный. Для суеверного же никакой мир не является общим, ибо он и наяву лишен здравого рассудка, и во сне не может избавиться от страхов» [11, с. 198]. Но на этот момент речи Апостолов, не допускающие ни сомнений, ни возражений, но призывающие не думать, но следовать вере (суеверию), основательно вытесняли натурфилософов, купировали Платона, сократическую школу исторгли как безусловное зло, а объективное видение мира подменили суеверием, при этом установку греков на политическую рефлексию изменили путем «усекновения головы» - рефлексировать дозволялось избранным, немного, только внутри собственного тела и в рамках трансцендентного - только в жанре исповеди и исповедуясь, по примеру Блаженного Августина. ${ }^{5}$

Заметим, храмы Аполлона были везде одинаковы: оракулы Аполлона (восседавшая на треножнике жрица - пифия) давали предсказания, двусмысленный характер которых, дающий широкое толкование, позволял коллегии жрецов воздействовать на греческую политику, но и, тем самым, отражал противоречивость восприятия самих греков, их готовность из противоречий ткать объективную, основанную на общем понимании вещей и явлений, картину мира, выражая политическую стратегию полиса $[12$, с. 66]. И если лесбосский храм принял к себе голову Орфея, дельфийский - разорванные части Диониса, то объединенные сиянием Аполлона, оба культа слились в один образ отчуждаемого бога, что отражал лишь общественные трансформации времен первых колонизаций человечества. Напомню, культ Диониса, учрежденный насилием, с его дионисиями и сатирическими дифирамбами, было народным (всеохватным) явлением, он

4. И не без иронии, видимо, уже в передаче Секста Эмпирика, Гераклит замечает: «...хотя разум

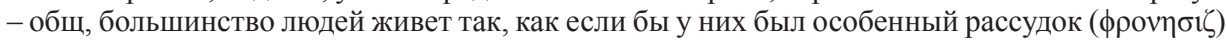
$»-$ [Секст Эмпирик. Против ученых, VII, 133 (после фр.1) - Фрагменты. Указ. изд.].

5. «Исповедь» Блаженного Августина, написанная примерно в 397-398 гг. н.э. 
отражал форму критического сознания, неся в себе и собою противоречия, что впитывались с молоком матери, ту полярность, что выражала общее для всех видение, - это был яркий всплеск сингулярности мышления древних греков,

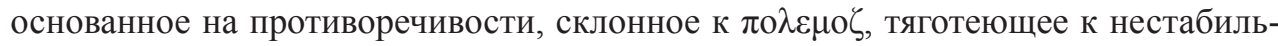
ности и детерминированное всяк переменами. Заметим, других философских школ, позволивших развиться полисной демократии, влиявшим и способствующим развитию полисной системы, как наиболее комфортной для человеческого общежития, позволивших древнему человеку стать на ноги, развернуть плечи, и осознать, что «человек - это звучит гордо», политически рефлексируя на политическую стратегию полиса, тем самым - мыслью и делом - участвуя в строительстве (вечном, не имеющем конца и края) мира , что всегда «неоднородный, пестрый и подверженный всяким переменам», других на тот момент не было. И здесь конечно велико влияние Мифа о Дионисе, что явил досократикам свои «стрелы познания» мира, а те протянули их 'ариадновой нитью’, чтобы ткать этос (морально-этический комплекс) общества, в зеркале которого и найдет свое отражение человек, взрослеющий и осознающий себя и героем, и богом, но ответственным и ответствующим. То объективное видение мира, коим располагал древний грек, не позволяет считать его «рабом» ни в каком бы то ни было значении. Человек, способный и склонный к политической рефлексии, вмещает в себя весь мир, он видя «изнанку» жизни, готов не только в перемене, стремится перелицевать ее, но при этом изменяется и сам: гераклитовским методом (практически вахтовым: начиная с себя).

И еще одно уточнение: культ Орфея возник в 6 в. до н.э. на основе аполлонодионисийского синтеза, как бы сопровождая распространение обоих, усиливая свет первого, и облагораживая полутона второго. Как нам кажется, в «неподчинении» и «насильственном воссоединении», о которых рассказывает Миф (тела Диониса и головы Орфея под портиком храма Аполлона), находится ключ и к пониманию внутренней раздвоенности самого человека: «естество» снимает тяжесть «личности», с ее интеллигибельностью, компенсируя трагизм индивидуализированности прямым действием - эскападой и бунтом [13, с. 52-53]. И поскольку в человеке живут одновременно экстраверт и интроверт: с одной стороны, он существует как бы вне себя в природном мире стихий, он отчужден от себя как от субъекта - вне тела, подобно разъятому Дионису; с другой стороны, он максимально замкнут, как орфик, для которого внешний мир - источник бед, страха и угрызений совести. С одной стороны, горестные филиппики рефрексирующего Орфея (сына музы Каллиопы, «мыслящей» дочери Зевса), а с другой - профанирующий смех терзаемого бастарда Диониса (незаконорожденного сына Зевса). Заметим также: голова Орфея, как бы освящала тело Диониса, уравнивала последнего в правах на благодать, коей для греков всегда была мудрость. И в этом суть карнавальных обертонов: один источает слезы и умирает, другой - смеется и возрождается. Один оплакивает порядок, взыскуя сознание, другой - несет собой беспорядок, черпая силы в «бессознательном». Один прячется в скорлупку-экзистенцию, другой - в 
критической жажде осмеяния рождает вселенскую мистерию [13, с. 54]. И таков порядок вещей, на котором строил свою натуральную философию Гераклит - на натуральном обмене всех на все, «заимообразно за счет другого», в чередовании противоположностей, сил, но, подчеркивая враждебный характер мира, он отмечал: «не к добру людям исполнение их желаний» [14, с. 234], обращая внимание на противоречивость натуры человека, раздираемого противоречиями, в результате чего поиски гармонии и целесообразности приводят к разрушению, сея хаотическую множественность иллюзий и непослушаний. И ведь именно так стала возможной «идея равенства и братства», что осенила своим темным ликом сознание «мятежных рабов» (заметим, по выражению Гераклита, тех «спящих, склонных к суеверию», что лишены общего видения, иначе мировоззрения) XX века и направила их на всеобщее «растерзание», но из суеверия, ожидая коммунистического святого причастия, в революционной вакханалии они проглотили исконный мир и создали свой «мир наоборот», где Мифу был уготован предел «запредельного» - ему предоставили медвежий угол фольклора ${ }^{6}$, «усекли» не рангом - на порядок - пустив кружить байкой и сказкой, рассыпав осколками символов и знаков, не связных и хаотичных, в результате чего человек перестал не только отражаться, ища отражений, но и верить, что мир - не иллюзия, принимая весь совокупный мир в формате разбитого зеркала троллей.

Словом, Миф о возрождающемся боге позволяет пролить некий свет на проблему человека, поставленного на грань выживания противоречиями дня сегодняшнего, и которую разрешить трудно, если следовать суеверному знаку - не оглядываться назад, страшась перспективы соляного столба, а не устремляться назад в прошлое на поиски судьбы, вопрошая у Клио и Мнемосины. И поскольку мир соткан из противоречий, и, принимая во внимание замечание самого Гераклита («вражда - таков обычный порядок вещей» [см. выше]), можно сказать, что всякое время пронизано противоречиями, то ни критическое самосознание, как карнавальное мироощущение, всегда присутствует в антропософской метрике человека. Именно Гераклит уподобил вечность движения кикеону (мятному напитку), «беспорядочно размешивающему и взбалтывающему поток событий» $[16, \text { с. 203] }]^{7}$. Но именно пропитанное духом противоречий время способно отразить (и отражало многообразно и разно) акт становления мечущегося меж огневых точек сознания, которое в смятении будет смешивать (словно буквально следуя гераклитовской ме-

6. А. Ф. Лосев допускал такую трактовку: «Пусть миф - сказка. Но это верно только тогда, если мы твердо запомним, что эта сказка есть реальное и даже чувственное бытие, что она ничуть не потустороння, а если, наконец, и потустороння, ...но так, что эта потусторонность является воочию как реальное, видимое и осязаемое жизненное событие» [14, с. 418], то есть возможно и сказкой, но на особых условиях - приоритетных: сначала Пушкин, потом - Остер, но, заметим, не вечной ссылкой в шутейный острог «небыличек».

7. Ср. также: «Ничего не постоянно, но все свалено в кучу, словно в кикеоне, и одно и то же: удовольствие-неудовольствие, знание-незнание, большое-малое, туда-сюда [все] кружится и сменяется в игре Века» [17, с. 203]. 
тодике - встряхивать и взбалтывать, «рассеивать и взаимосцеплять» [17, с. 203]), пытаясь сконструировать цельный образ современной ему действительности (являющейся упорядоченным космосом, в котором все движется своим беспорядочным курсом) после «бури и натиска», что пронеслись над головами многих, увлекая в свой кикеон обычным порядком вещей [18]. А ведь всяк обычный порядок имеет свой распорядок, уже отмеченный Мифом, занесенный в реестр мойр, поскольку «все происходит согласно судьбе, и все сущее слажено в гармонию через противообращенность» [19, с. 201].

Если XVII века был веком колонистов - всплеском пиратской стратегии новых цивилизаций и новейшего времени, освященного «государственного пиратства», то XVIII стал золотым веком «частного разбоя»- пиратством крупных землевладельцев и олигархов, когда собственник наслаждался своим богатством и вседозволенностью, что обернулось разорением крестьянства, разрушением гильдий, которые могли утешаться лишь признанием собственной бедности (законной) по лености и разгильдяйству - словом, тем, что не умели деньги отдавать в залог. По сути, век пиратства продолжался уже не на чужих территориях, в пределах родного государства - принцип «захвата чужого» объявлялся законным по «праву сильного» - таким образом, личный интерес объявлялся законом природы, предначертанным для того, чтобы служить всеобщему благу (!), и как льстивый симулякр вручался тому большинству, которому была уготована только религия, а не свобода мышления, суеверие и страх (напомним слова Гераклита: «Для суеверного же никакой мир не является общим, ибо он и наяву лишен здравого рассудка, и во сне не может избавиться от страхов» (см. выше)). Так, «любовь к деньгам преобразовалась из источника зла в движущуюся силу общественной жизни» [20, с. 77], а стратегия пиратства была узаконена, хотя во все былые времена, начиная с архаики, пираты были и жили вне полиса и закона. ${ }^{8}$

Памфлет Т. Мора «Государство Утопа» (первоначальное название) явил притчу государственного уложения, который преобразовался в схоластический кентавр на глиняных ногах - пять сотен лет этому «символическому обмену», что поспособствовал «Трудам и дням» Гесиода, одной из главной книг древнего всеобуча, пеленавшей умы античности, эллинизма, средневековья, возрождения, трансформироваться в «Труд и смерть» Бодрийяра, где «труд» не просто понижен в правах - ему уготован лишь один модус - смерти: «Труд ...противостоит как медленная смерть - смерти насильственной. ... он единственная альтернатива труду - не свободное время или же не-труд, а жертвоприношение» - таков вердикт обществу потребления, вынесенный в 1976 г. [21, с. 103]. Если в качестве приложения к цитате рассмотреть миф о Минотавре, то получится, что Тесей, вспахивая поле под зубья дракона, приуготовлял для себя обряд погребения. Но если продолжить цитату: «Трудящийся всегда остается человеком, которого не

8. Доказательства тому хранят свидетельства и размышления Гомера, Страбона, Плутарха и др. 
стали казнить, которому отказали в этой чести. И труд предстает прежде всего как знак унижения, когда человека считают достойным одной лишь жизни» [21, c. 103], то, в приложении к тому же Мифу, следует предположить, что для самого Тесея процесс вспашки был унижением, - скорее он принимался им (или понимался, что одно и тоже) как часть ратного дела, того же подвига (греч. єрүо , имеющее несколько значений: «работа», «дело», «подвиг», «произведение», или $\alpha \theta \lambda \circ \zeta$ - «борьба», «труд», «подвиг», демонстрируют тождественность этих понятий для древнего грека, что фиксирует греческий словарь, что правит сознанием не хуже Талмуда, - эти значения уравнены в правах $)^{9}[22]$. Такие фиксации уравнивания/тожества труда и подвига оберегает теория номинации (ономасиология), что проистекает со времен античности, когда теория именования составляла важную часть философии, что было обусловлено интересом к природе языка, когда значение того или иного имени определялось фактом истинности или ложности, зависимостью от говорящего или слушающего, особо выделялись универсалии природа общих понятий.

Как же расправился французский исследователь социума с общим понятием «труда» в конце XX века? Бодрийяр же являет анти-реверс: «Капитал ..., отлагая [людские] смерти, он превращает их в рабов и обрекает на бесконечное унижение - жить в труде» [21, с. 103]. Не доблесть и подвиг, а стыд и мука! Не радость и счастье труда, но садомазохистская сладость! Можно подумать, что сам труд предпочитает «спящий режим» смерти! Так, миф вторичной (знаковой, символической) системы совершает революционный взлом сознания, который необходим секулярному меньшинству как оружие и метод подавления и управления - это политическая философия революционеров Просвещения: религия вводилась как суррогат Мифа, упрощенный симулякр архаических представлений о загробной жизни, как леденец мировоззрения.

Миф, что направлял на свершения, как акт подвига и труда был исторгнут, поскольку в нем, помимо рационального зерна (практичность греков вне подозрения как жена Цезаря - даже натурфилософы обеспечивали себе существование собственным трудом $\left.{ }^{10}\right)$, хранился стойкий позитивизм древно-

9. От греч. $\alpha \rho о \omega$ (пахать), видимо, произошло и др.-русск. и ст.-слав. «орати» в знач. «пахать», как и болг. «ора», сербохорв. «орати», словен. «оrati», польск. «оrac», «orze», чеш. «orati», лат. «aro», «-are», ср.-ирл. «airim», гот. «arjan»- с тем же значением, причем к значению предикативному (глаголу действия) добавляются номинативные - «плуг» и «вспаханное поле», которое, видно, нередко становилось и полем брани, поскольку слово др.-рус. «ратай» (ст.слав. paтаи, болг. paтай, сербохорв. pamaj, ратар, словен. ratej, др.-чеш. rataj, слвц. rataj, польск. rataj) помимо значения «пахарь» имело второе значение «воин», то есть обладало омонимом, одинаково звучащим словом, но со связным значением, что является исключением для такого широкого в языкознании явления, как омонимия, и эта связь прячется в глубокой старине Мифа. И между тем от «ратая» (пахаря или воина) пошло слово «рать» (войско) и «ратище» (копье) (заметим, этимология хранит много ответов, помогая ономасиологии противостоять супрематизму структурализма). [22, с. 148, с. 447-448].

10. Гераклит был удачлив в торговле, Гиппократ и Эмпедокл врачевали, Фалес проявлял изобретательность в военной тактике, полисном управлении и торговле, Архит семь раз был стратегом Тарента. 
сти, введший агональный принцип жизни, предназначенный для неспящих, но активных, стремящихся объективно познать мир и оставить свой след на земле, хотя бы в виде глиняного горшка, или ковра, но сделанного таким образом, что ему позавидовали бы боги, и дабы не обидеть богов, каждый, включенный в агон, ставил рядом со своей подписью имя бога, которого брал себе в союзники для своих ратных (ратоборческих, творческих) дел, ежедневных, неустанных, но сладких необоримостью подвига, деяния, что направлено в мир для других, для свершения. Напоминаем шепот Гераклита, что время растворило атомарно: «Для бодрствующих существует один общий мир, а из спящих каждый отворачивается в свой собственный».

Однако политическая рефлексия имеет один существенный недостаток краткость исторической памяти, которая должна время от времени приводиться в чувство, освежая вехи событий и мудрость чужих рефлексий, с тем, чтобы не возникали когнитивные диссонансы вольно (произвольно) или злым умыслом политических феноменов (войны, государства, стратега-политика, политической власти и пр.), ломающих мембраны человеческого общежития - этос, философию культуры, искусство вместе с наукой и тягой к труду. ХХ век (и длящаяся первая четверть XXI в.), как яркая иллюстрация нескончаемых войн и перманентных революций, как век мировых и локальных конфликтов, демонстрируя неразрывную связь с античным мифом, ХХ-й рассыпал зубья мифологий, перекраивая мир и принципы государства, разрушая границы и империи, развязывая новые войны, множа этнические конфликты, сметая ценностные ориентиры и меняя антропологические признаки, расподобляя сущностное в человеке: лишая Слова и Дела.

\section{БИБЛИОГРАФИЯ}

1. Плутарх. Исида и Осирис. - М.: Эксмо, 2006. - 463 с., Гераклит цит по: [Vors. I, 12, В 51].

2. Плотин, III, 2[47], 16, 48 Н.-S. - Гераклит. Фрагменты. / Фрагменты ранних греческих философов. Ч. І. - М.: Изд-во «Наука», 1989 [Die Fragmente der Vorsokratiker. Grichisch und Dentsch von HERMANN DIELS, hrsg. V. W. KRANZ, Bd. I-III. B., 1951-1952]. - 576 c.

3. Филодерм. О благочестии, 6a (с. 70 Gomperz). - Гераклит. Фрагменты. / Фрагменты ранних греческих философов. Ч. І. - М.: Изд-во «Наука», 1989. - 576 с. [Die Fragmente der Vorsokratiker. Grichisch und Dentsch von HERMANN DIELS, hrsg. V. W. KRANZ, Bd. I-III. B., 1951-1952].

4. Плотин, IV, 8[6], 1, 11 Н.-S. - Гераклит. Фрагменты. / Фрагменты ранних греческих философов. Ч. І. - М.: Изд-во «Наука», 1989.

5. Ипполит. Опровержение, I, 4, 2 (Dох. 559). - Гераклит. Фрагменты. / Фрагменты ранних греческих философов. Ч. І. - М.: Изд-во «Наука», 1989.

6. Иоанн Цец. Хилиады, II, 723, Leone. - Гераклит. Фрагменты. / Фрагменты ранних греческих философов. Ч. І. - М.: Изд-во «Наука», 1989.

7. Порфирий. О пещере нимф, 29. - Гераклит. Фрагменты. / Фрагменты ранних греческих философов. Ч. І. - М.: Изд-во «Наука», 1989.

8. Плутарх. Исида и Осирис. - М.: Эксмо, 2006. - 463 с. 
9. Ипполит, IX, 9,4 (с. 242, 5W), Кельс у Оригена, Против Кельса, VI, 42, (II, c.111, 9Koetschau). - Гераклит. Фрагменты. / Фрагменты ранних греческих философов. Ч. І. М.: Изд-во «Наука», 1989.

10. Стобей, III, 1, 179 (III, с. 129 Н.) («О добродетели»). - Гераклит. Фрагменты. / Фрагменты ранних греческих философов. Ч. І. - М.: Изд-во «Наука», 1989.

11. Плутарх. О суеверии, 166. - Гераклит. Фрагменты. / Фрагменты ранних греческих философов. Ч. І. - М.: Изд-во «Наука», 1989.

12. Мифология: ИФС. - СПб., 1996. - 790 с.

13. Меньшикова Е. Р. Гротескное сознание: явление советской культуры. - СПб.: Алетейя, 2009. - $296 \mathrm{c}$.

14. Стобей, III, I, 176. - Гераклит. Фрагменты. / Фрагменты ранних греческих философов. Ч. І. - М.: Изд-во «Наука», 1989.

15. Лосев А. Ф. Диалектика мифа / Лосев А. Ф. Из ранних произведений. - М.: Изд-во «Правда», 1990. - $656 \mathrm{c}$.

16. Хрисип у Плутарха, О противоречиях стоиков, 1049F (=SVF II, № 937). - Гераклит. Фрагменты. / Фрагменты ранних греческих философов. Ч. І. - М.: Изд-во «Наука», 1989.

17. Лукиан. Продажа жизней, 14. - Гераклит. Фрагменты. / Фрагменты ранних греческих философов. Ч. І. - М.: Изд-во «Наука», 1989.

18. Меньшикова Е. Р. Карнавальное сознание. // Дискурс, 2000. №8/9. С. 19-26.

19. Диоген Лаэртий, IX, 7. - Гераклит. Фрагменты. / Фрагменты ранних греческих философов. Ч. І. - М.: Изд-во «Наука», 1989.

20. Доусон К. Г. Боги революции. - СПб: Алетейя, 2002. - 332 с.

21. Бодрийяр Ж. Труд и смерть. / Бодрийяр Ж. Символический обмен и смерть. - М.: Добросвет, 2000. - 387 с.

22. Этимологический словарь русского языка. В 4 т. Т. 3 / М. Фасмер. - 4-е изд., стер. - М.: Астрель: АСТ, 2007. - 832 с.

23. Меньшикова Е. Р. Миф как натуральный обмен. // CredoNew, 2017, №№ 1, 2, 3.

24. Menshikova E. R. The Natural Landscape of Philosophy (political reflaction of Heraclitus and Aristotle). // 29 $9^{\text {th }}$ International Conference of Philosophy "Greek moral and political philosophy-From Pre-Socratics to Neo-Platonism” (Jule 7-11, 2017, Rhodes). Paper Abstracts. - Rhodes, 2017.

25. Menshikova E. R. The Natural Landscape of Philosophy (The Political Reflection of Heraclitus and Aristotle). // Philosophy Study, V. 8, N.1, 2018. 